\title{
Ethnic Conflicts, Democratic Governance and Administration in Nigeria: The Relevance of Hislope's Generosity Moments Theory as a Solution
}

\author{
Akwara, Azalahu Francis (Ph.D) \\ Department of Political Science, \\ Federal University, Taraba State, Nigeria. \\ Agba, Michael Sunday (Ph. D) \\ Department of Public Administration, \\ University of Calabar, Calabar. Cross River State, Nigeria. \\ Corresponding Author: mikagbaagba@yahoo.co.uk

\section{Edino, Ferdinand Ojonimi (Ph.D in view)} \\ Department of Public Administration, \\ Kogi State University, Anyigba, Kogi State, Nigeria.
}

\section{Doi:10.5901/mjss.2013.v4n11p356}

\section{Abstract}

\begin{abstract}
Ethnic conflicts are not new in Nigeria. They have existed in the regions long before British colonization of the various ethnic nationalities that comprise the country. The persistence of ethnic conflicts in Nigeria has become a threat to peace, unity and democratic governance and administration in Nigeria. This paper examines the nature and causes of ethnic conflicts in Nigeria's political processes and how these conflicts have militated against the development of democracy and public administration in the country. It also examines the efforts made by the various governments in the country to resolve the problem; and finally examines how the application of Hislope's "generosity moments" theory to the Nigerian situation could serve as a solution to ethnic conflicts in the nation's political processes and democratic governance in the country as earlier adopted solutions have been ineffective. The paper finds that there are structural factors inherent in the Nigerian federation that militate against the resolution of ethnic conflicts and consolidation of democracy in the country which would also militate against the working of Hislope's generosity moments theory and recommends some structural adjustments in the nation'sconstitution as a solution to ethnic conflicts and democratic governance in the country. The paper concludes that if the structural adjustments are made, the Hislope's generosity moments theory would provide an adequate solution to the problem of ethnic conflicts and democratic governance in Nigeria.
\end{abstract}

Keywords: generosity moments; ethnicity; ethnic conflicts; regime transition; political transition;

\section{Introduction}

The challenge of ethnic conflicts in Nigeria is not a recent phenomenon. It has existed in the region long before the British colonized the various ethnic nationalities that comprise the country today. The inadequate understanding of ethnic phenomenon in Nigeria made the colonial government in the country to set up the Sir Henry Willink's Minority Commission on September 27, 1957, to look into the problems of the minority ethnic nationalities that had complained to the colonial government of being marginalized in the country's political processes. The Willink's Commission did not offer any solution to the minority problems in the country then, and these problems lingered into an independent Nigeria where they have become worse.

The Independent Nigerian Governments tried solving the problem through state creations exercise in 1962, 1966, 1976, 1986 and 1996. And in 1979, the "federal character principle" was introduced into the country's constitution under the Fundamental Objectives and Directive Principles of State Policy, aimed at making the governments in the country representative of the various ethnic groups and peoples of the country. Rather than solve the ethnic question in Nigeria, these measures reinforced the problem and even posed new problems that complicated the ethnic question, leading to the mismanagement of the nation's economy and to the creation of a "cult of mediocrity" (Achebe, 1983) in the nation's 
administrative bureaucracy.

Some political parties in the country resorted to the zoning of certain political positions to some ethnic regions as a measure of stemming down the tide of ethnic crises in the political process but there were no measures in place to ensure that the positions rotated among the various ethnic nationalities and geo-political zones or regions in the country. These zoning policies became sources of personality clashes and ethnic crises that sometimes led to political assassination and balkanization of political parties that had national appeals.

All these devices have failed to solve the ethnic question in Nigeria and the ethnic crises become more intense during political and regime transition periods. The intensities of these conflicts show that ethnic conflicts are incompatible with democracy as the conflicts threaten the peace, security, development, the legitimacy of the regimes and consolidation of democracy in the country. This has made the government to adopt the method of sending military expeditions to ethnic regions where the crises exist; and to ethnic regions that one way or the other "threaten" the peace, security and the corporate existence of the country; after which administrative panels of inquiry are established to investigate the "remote and immediate causes of the conflicts, and to make recommendations to the government". However, the reports of these panels are rarely made public in the country.

More than two decades ago, Hislope (1998) postulated a "generosity moments" theory as a solution to ethnic conflicts in multi-ethnic societies. The theory holds that in the course of regime change in a multi-ethnic society, that there exists a critical juncture - a generosity moment- at which the dominant ethnic groups must decide how to respond to minorities demands; and that elites' decisions at such points establish distinct trajectories along which transitions (and consolidation) unfold and or, are reversed. And suggested that a generous liberal approach towards minorities is the best way to ensure peaceful transitions, and secure the security and legitimacy of the state. The elites are therefore, significant causal factors of transitions and consolidation of democracy in a polity.

Every political and or regime transition period in Nigeria is a generosity moment - the 1979 political transition period of General Olusegun Obasanjo; the 1993 transition period of General Ibrahim Babangida; the 1997 political transition programme of General Sanni Abacha; the 1999 political transition period of General Abdulsalami Abubakar; and the 2003 regime transition period of Chief Olusegun Obasanjo; and the 2007 regime transition period of Chief Olusegun Obasanjo were such identifiable moments that call for generosity by ethnic majorities towards the ethnic minorities in the country. All these periods had been tense and violent, and threatened the legitimacy of the government and the corporate existence of the country because two particular ethnic majorities (the north and the west) that have dominated the politics and economy of the country since 1966 have refused to be generous to the other ethnic nationalities in the country.

During the regime transition of 2007 in Nigeria, the minorities ethnic nationalities especially those in the Niger Delta Region and the Igbo ethnic majority of the Eastern Region that has been marginalized in the nation's political process since 1966, were poised to have the highest political posts in the country. They felt that they are no longer satisfied being spectators in the Nigerian political process and threaten the corporate existence of Nigeria should they be denied the opportunity to occupy the highest political post in the country. Their plights really called for "generosity" by the other majority ethnic groups in the country during the 2007 regime transition. This may have accounted for the selection of the vice-presidential candidate of the ruling Peoples' Democratic Party (PDP) from the Niger Delta Region. This study therefore examines the ethnic factor in Nigeria's political process and the prospects of the generosity moments theory being a workable solution to the crises.

\section{Statement of the Problem}

Nigeria has the largest number of ethnic nationalities amongst all African countries. It is believed that there are more than 400 ethnic nationalities in the country and recent discoveries are being made of new ethnic nationalities in the northern region of the country. With so many ethnic nationalities purposely and forcefully put under a roof by the colonial forces without due regard for their ethnic differences, there is bound to be conflicts amongst them.Furthermore, these ethnic nationalities have never come together since the departure of the colonialist, to discuss the basis under which the country should continue to remain as one united geo-political entity called Nigeria; but have through the colonial design, been forcefully made to remain in that colonial arrangement by one ethnic group in the country. It is therefore the purpose of this paper to investigate why after fifty years of Nigeria's existence as an independent country, the struggle for political power in Nigeria's has been characterized by ethnic conflicts and ethnic considerations rather than issues of development and good governance; how have these ethnic conflicts in the political process affected the consolidation of democratic rule in the country, what measures have been adopted by the various governments in the country to solve the 
problems generated by ethnic differences in the political process and how successfulhave these measures been; and, what are the prospects of solving these ethnic problems in Nigeria through the application of Hislope's generosity moments theory in the country's political process.

\section{Ethnicity and Ethnic Conflicts in Nigeria}

Ethnicity is a political concept and denotes the expression of ethnic sentiments or ethnic nationalism. It involves the practice of ethnic ideology which enables a group to exploit natural differences in nationality for specific purposes. As Igwe (2002) pointed out, it is an outward-looking chauvinistic attitude towards one's nationality and cultural group with a correspondingly suspicious and hostile attitude towards others, especially those held to be in competition with ones own ethnic group.

Ethnicity manifests in the political, economic and cultural processes of a country and is propagated by the family, economic groups, and political groups in the labor process. As Nnoli (1989) noted, it is determined by the size of a linguistic group, location of the group, strength and cohesion of its leadership, the nature and leadership of underprivileged classes, foreign influences and dominant ideology.

Ethnic conflicts had been in existence in Nigeria before the advent of colonialism. Ethnic wars were fought over natural resources, farmlands, grazing lands, water supply, fishing rights, hunting rights, items of trade such as slaves, ivory, gold, etc. Later, religious beliefs and power positions became issues keenly contested in and across the length and breadth of the country, leading to wanton destruction of lives and property across the country (Ifemesia, 1965; Aderibigbe, 1965; and Tamuna, 1965).

Ethnic conflicts in Nigeria are therefore generally caused by (a) struggles over natural and economic resources by ethnic nationalities, (b) as a result of migration, and (c) state and empire building processes by ethnic nationalities (Ifemesia, 1965; Aderibigbe, 1965 and Tamuno, 1965). Some of the expansionist tendencies by some ethnic nationalities were successful in some areas, while in so many areas, they were checkmated by the ethnic militias of the invaded ethnic regions and nationalities; and by the advancement of the colonial occupation forces (Akpofuru and Crowther, 1965).

Most ethnic conflicts in Nigeria are outcomes of foreign influences - colonization and unification of disparate peoples around the River Niger area into a country by the British colonial forces without due consideration for their ethnic diversities (Balewa, 1948); western education which led to social mobilization and the creation of new social classes or what Deutsch (1961) called the "new marginal men", and whom Nnoli (1989) referred to as "educated and insecure elites" who have resorted to organizing collective ethnic support to ensure their successes in the competition for national posts and resources because they have either failed to achieve, or, the available national institutions have failed to accommodate them and their ethnic interests.

The same social mobilization via education created what Nnoli (1989) has called "middlemen minorities" who took advantage of the unification of the various ethnic nationalities into a country called Nigeria, to venture out of their ethnic regions for business ventures (this is particularly true of the lbo ethnic group in Nigeria. There is a popular saying that wherever you do not find an Ibo-man, no one is there. - just leave the region). In their host ethnic regions, they became ethnic minorities and targets for all forms of ethnically motivated attacks because of their business acumen.

Finally, ethnic conflicts are endemic and rampant in the country because of the multiplicity of ethnic groups in the country. It is estimated that Nigeria has more than 400 ethnic nationalities and linguistic groups (Murdock, 1959). This is too much for a single country. It is extremely difficult to have 400 or more ethnic nationalities under a roof without conflicts each day. With the multiplicity of ethnic nationalities in the country, it is extremely difficult to achieve a "unity in diversity".

Nigeria is not a country; it is merely a geographical expression (Awolowo, 1946). It is evident that ethnic conflicts in Nigeria took a national outlook with the formation of the Nigerian state by the British. Simply put, it was the colonization of Nigeria that halted state formation processes in the present day Nigeria, and set the stage for ethnic conflicts which have characterized the country's political processes and militated against the development of stabledemocratic governance in the country. Ethnicity has become a potent force in politics. It was the basis for the formation of nationalist movements during colonial era in Nigeria (Coleman, 1963), and the basis for political party formation, membership and support (Sklar, 1963). 


\section{Measures Taken to Combat Ethnic Conflicts in Nigeria}

The various governments in Nigeria have adopted varying measures to combat ethnic conflicts in the country, and most of these measures have not been effective hence the persistence of the problem in the country especially during political and regime transition periods. The measures adopted so far have been:

1. Establishment of administrative commissions of inquiry into the conflicts ${ }^{1}$.

2. The creation of autonomous ethnic regions (states and local governments) for the ethnic regions where such creation would reduce the ethnic advantage of others (considered as opponents) and, or, advance the ethnic interests of the creators of the autonomous ethnic regions².

3. The entrenchment of the "federal character principle" in the constitutions of the country under the fundamental objectives and directive principles of state policy3.

4. Sending of military expeditions to the ethnic regions in conflict to give military solutions to the conflicts 4 .

5. Zoning certain key political posts to certain ethnic nationalities and, or, ethnic regions in the country5.

Almost every government in the country has adopted the use of administrative panels of inquiry to investigate and resolve ethnic conflicts in the country. The most popular of these panels was the Sir Henry Willink's Minority Commission set up by the colonial government on September 27, 1957 to investigate the complaints of the various ethnic minorities in the then three geo-political zones that formed the country - the Eastern, Northern and Western Regions. They were the federating units in the formation of Nigeria.

The ethnic minorities in the then three geo-political zones in the country had complained of being marginalized in the political and economic processes of their geo-political zones in particular and the country in general, and demanded for the creation of autonomous geo-political zones for them in their various ethnic regions. The three ethnic majorities in the then three regions - the Ibos in the East, the Hausa/Fulani in the North and the Yorubas in the West took diverse stands on the issue, while the Ibos of the east and Yorubas of the West favored the creation of autonomous geo-political zones for the ethnic minorities across the country and the redrawing of the geo-political maps of the regions; the Hausa/Fulanis of the North rejected such creation as it would rob them of their political advantage of dominating not only the politics of the Northern region but also that of the country as a whole (Orjiakor, 1981; Blitz, 1965). Though there were disagreements among the ethnic minorities themselves over the membership of the new geo-political zones to be created across the country (Orjiakor, 1981; Coleman, 1963; Sklar, 1963), the colonialists had said that such creations would have created new minorities and new minorities problems; and would have also delayed the Nigeria independence (Blitz, 1965).

But the Sir Henry Willink's Minority Commission was not disposed to solve the minority problems. It noted in its report that "real danger existed among the minority ethnic groups in all the geo-political zones in the country" then. The commission was therefore of the opinion that creating new autonomous ethnic regions in each of the existing geopolitical zones would create problems as great as those it sought to solve. It ended up recommending the creation of special and minority areas and one of such recommended special area is the present day crises-ridden Niger Delta Region in the country. Except the Sir Henry Willink's Minority Commission, no other administrative commission of inquiry into ethnic conflicts in the country has had its report made public for obvious reasons.

The use of state creation to solve ethnic conflicts found favour before the successive indigenous governments in the country, as they believe that the state creation exercise would reduce ethnic tensions across the country. This led to the state creation exercises by the various governments in 1962, 1966, 1976, 1986 and 1996, and ethnic and cultural interests guided such state creation exercises (Ikejiani and Ikejiani, 1986; Awolowo, 1947 and Ellah, 1983). The state creation exercises have tended to produce "new elites" or "contending elites" in the various geo-political zones who constitute new problems of accommodation in the system. They have also produced new majority and minority ethnic groups in the newly created states or geo-political zones, an issue the Willink's Minority Commission had noted and warned against. The ethnic interests of those in power or operators of the various regimes have guided almost all state and local government creation exercises in Nigeria.

The use of the federal character principle as a means of solving ethnic conflicts endemic in the Nigerian political process was introduced in 1979 under the Fundamental Objectives and Directive Principles of State Policy in the 1979 Constitution and in all other subsequent constitutions. The federal character principle aims at making it difficult for the government or any of its agencies to be dominated by any one ethnic group in the country by insisting that the composition of the government of the nation, or any of its component states or local government councils, and or, their agencies shall be carried out in such a manner as to reflect or recognize the pluralist nature (ethnic diversities) of the country and or its component states, local governments and agencies. It should be in such a way as to promote a sense 
of belonging and loyalty among all peoples of the country. Such composition must reflect the "federal character".

The federal character principle however fell short of solving ethnic conflicts and problems endemic in the polity during political and regime transitions because it failed to give equal opportunities to all Nigerians or ethnic regions to produce in turns, the occupants of the highest political seats in the country. This would have eliminated the ethnic crises and violence that accompany the struggles for such posts in the country. This simply means that the members of the minority ethnic groups would be accommodated in government only in the places where the majority ethnic groups want them to be; and since politics is a matter of majority votes, the minority will always remain out of power. So the federal character principle falls short of solving ethnic conflicts in Nigeria. As Achebe (1983) noted, it has led to the creation of a "cult of mediocrity" because incompetent persons get these power positions due to their ethnic origins, religion and other undue considerations. And this has also led to the mismanagement of the nation's economy and corruption among political office holders. This has really affected the development of democratic governance in the country.

The next method adopted by the political elites themselves rather than the government as solution to ethnic conflicts during political and regime transitions is the "zoning" of key political posts in the political party, and in the nation if victorious at the polls, to certain ethnic regions or ethnic nationalities.

The National Party of Nigerian (NPN) employed this strategy to reduce ethnic conflicts during the 1979 political transition in Nigeria, and this saw the Party chairmanship going to Chief Akinloye of the Yoruba Western region, Presidency to Alhaji Shehu Shagari of the Hausa/Fulani group of the North and Vice President to Chief Alex Ekwueme of the Ibo ethnic group of the Eastern region. Some other posts in the legislatures - the speakers and deputy speakers of the Senate and House of Representatives were also zoned to ethnic nationalities. This zoning system attracted most conservative elites of the various ethnic regions into the Party and made the Party victorious at the 1979 Presidential election.

The desire of the other ethnic groups to have the Presidency zoned to another ethnic group in the regime transition of 1983 almost tore the NPN to shreds. Chief M.K.O. Abiola, a Yoruba businessman from the Western region that had wanted the Presidency was told by Alhaji Umaru Dikko of the Hausa/Fulani North that the Presidency was not for sale to the highest bidder. Chief Abiola with his Yoruba supporters left the NPN.

The NPN maintained the 1979 zoning system in 1983 and emerged victorious at the Presidential election, and the desire of the Hausa/Fulani ethnic majority not to leave the Presidency to any other ethnic group in the country led to series of military coups between 1983 and 1999 that saw the Hausa/Fulani group still in control of the central government.

The Peoples Democratic Party (PDP) employed a zoning system in the 1999 political transition period and became victorious. Retired Genereal Olosegun Obasanjo of the Yoruba (Western region) won the Presidency under the platform of the PDP. His desire to have a second term in office triggered off conflict between him and the vice president Alhaji Atiku Abubakar; the Yoruba ethnic group and the elites of the other ethnic nationalities in the party especially those from the Northern region. This conflict became personalized, heated the polity, and threatened the peace, security and corporate existence of Nigeria, and aborted the several attempts by General Obasanjo to remain perpetually in power after the second term in office; just like his Hausa/Fulani military counterpart did. Eventually the Presidency went back to the Northern Hausa/Fulani ethnic group.

From the lessons of zoning system in the country, it has becomes clear that the peace, security and corporate existence of the country can be secured and democratic governance evolved and sustained, and even consolidated if the majority ethnic groups can be generous not just to one another but to all other ethnic groups especially the minorities, in the political processes of the country. And this can be achieved through the entrenchment of zoning of political offices in turns, to ethnic regions or nationalities in the country's constitution.

\section{Hislope's Generosity Moments Theory and Ethnic Conflicts in Nigeria}

Hislope's (1998) thesis states that in the course of regime change in a multi-ethnic society, there is a critical juncture - a "generosity moment" at which dominant ethnic groups must decide how to respond to minority demands. At such points, elites' decisions establish distinct trajectories along which transition and consolidation processes unfold, and or, are reversed. Therefore, a generous liberal approach by the majority ethnic groups towards the minorities is the best way to ensure peaceful transition, win the democratic consent of the minorities, and secure the legitimacy of the state.

For this method to work out, Hislope (1998) maintains, it is the elites that matter. The elites of the majority and minority ethnic groups are seen as significant causal factors during transition and consolidation of any new regime. The elites of the majority ethnic groups have to be conciliatory and promote avenues of dialogue and cooperation with those 
of the minority groups to reduce the prospects of inter-ethnic violence in the polity. The elites of the majority ethnic groups must be able to identify moments which are conspicuous for generous overtures and intervention towards those of the minority groups - how and when to be generous, what structural factors should be put in place for the generosity to work out, and to ensure that the generosity does not lead into a "slippery slope" for the minorities who may become unduly demanding, making impossible demands and become insatiable thereby holding the entire nation to ransom. To overcome all these problems, the elites of both the majority and minority groups must promote dialogue and cooperation to produce factors that are acceptable to all groups.

Hislope (1998) also noted that certain structural factors prevent the elites of the majority ethnic group from being generous towards the ethnic minorities, and these are: the demographic pattern of the society; the existence of historical memories of violence between the groups; the existence of contested borders; if being generous would not create a 'slippery slope' for minority demands; and the existence of a large number of ethnic groups in the society which would make it difficult (but not impossible) to find a solution that would satisfy all groups.

Unfortunately, these structural factors identified by Hislope do exist in Nigeria. Though it is difficult to get the ethnic majorities to be generous to the minorities, it is not impossible because, successive governments in the country have created most of these structural factors that impede generosity especially the colonial administration in the country. And lessons from the internal arrangements of the political parties to zone out political posts show road maps towards generosity and should be pursued in the interest of peace, unity and progress and development of democratic governance in the country.

\section{Generosity Movements in the Nigerian Political Process}

Several moments could be identified as being proper for the majority ethnic groups to have been generous to the minority ethnic groups in the nation's political process (but they never were). The first was in 1957 when the minorities wanted autonomous ethnic regions across the country. The British colonial administration in the country and the majority ethnic groups that dominated the regions did not want it. Even the creation of the Mid-Western region out of the Western region in 1962 was under crises conditions.

The second opportunity was in 1979 political transition from military dictatorship to civil democracy. The Hausa/Fulani and the Yoruba groups having been in power from 1958 to 1978 would have given other ethnic groups the opportunity to occupy the highest political posts in the country.

The third was during the 1983 regime transition when the civilian President, Alhaji Shehu Shagari, sought a reelection under the NPN thereby destroying the zoning system introduced by the NPN. This desire to remain in power against the good intentions of the zoning system evolved by the National Party of Nigeria (NPN) created ethnic crises that led to the Northern military elites taking over political power in 1984.

The fourth was in 1993 during the political transition period of General Ibrahim Babangida. His annulment of the 1993 Presidential election won by Chief M.K.O. Abiola of the Yoruba ethnic group of the Western region set the stage for violent ethnic clashes between the Yorubas and Hausas all over the country. The ethnic conflicts may have made the Northern elites to allow the presidency to the Yoruba ethnic group of the Western region in the 1999 political transition period under the Democratic Party.

The fifth was in 1997 during the political transition period of General Sani Abacha. General Sani Abacha's desire to succeed himself in office as an elected head of state intensified the ethnic conflicts between the Hausa/Fulani group which the General represents, and all other ethnic groups in the country.

The sixth was during the political transition period of General Abdulsalami Abubakar in 1999. General Abdulsalami Abubakar simply handed over power to an ex-military dictator General Obasanjo (a member of the majority Yoruba ethnic group) as a civilian head of state. Retired General Olusegun Obasanjo was touted as the "President we can trust" by the Northern elites because he had handed over power to one of the Northern elites (Alhaji Shehu Shagari) in defiance of the 1979 constitutional provisions on the election of the president.

Alhaji Shehu Shgari did not meet the constitutional provisions to be declared the duly elected president of the Federal Republic of Nigeria in 1979 and the issue became a legal battle between Chief Obafemi Awolowo (a member of the majority Yoruba ethnic group of the western region) who contested for the presidency under the Unity Party of Nigeria (UPN), and Alhaji Shehu Shgari who contested for the same post under the National Party of Nigeria in 1979. The Supreme Court of Nigeria instead of ordering for a re-run of the elections, awarded the post to Alhaji Shehu Shagari of the NPN, and he was sworn in by General Obasanjo. General Obasanjo can be trusted to return that same office to a Northerner, and he did so in 2007. At this time, the northern Hausa/Fulani ethnic group was not generous to the Yoruba 
ethnic group of the western region because the Yoruba majority ethnic group had become more cohesive than the Hausa/Fulani group due to the events of the June 12, 1993 Presidential election, more very restive, and poised to balkanize the nation, should they miss the opportunity of producing the president; and the Hausa/Fulani group of the north was not sure of the support of the Ibos of the eastern region, and of the support of the minority ethnic regions in the northern and eastern regions to pull back the western region should there be a secession by the western region. There therefore seem to have been a "tacit agreement" between the elites of the two majority ethnic groups that power must elude the Ibo majority group of the eastern region, and be returned to the Hausa /Fulani group of the north after the Yorubas had taken their turn. For there to be a generosity, power must change hand from a majority ethnic group that has held power for a long time, to a minority ethnic group that has never held the power position for the first time, or to a politically marginalized ethnic majority group that has not held such power position for a very long time.

The seventh moment was in 2003 during the regime transition of Chief Olusegun Obasanjo. His desires to recontest as the President in 2003 set the nation on fire, and a series of personality clashes between the president Chief Olusegun Obasanjo, and his Vice, Alhaji Atiku Abubakar who also wanted the same post. Chief Olusegun is from the Yoruba group of the west, and Alhaji Atiku Abubakar from the Hausa/Fulani of the north. The desire of the Igbo ethnic group of the east, and the desire of the ethnic minorities of the Niger-Delta region for the post, intensified ethnic crises between the minorities of the Niger Delta who ask for a fiscal federalism under the slogan of "resource control", and the Ibos on the one hand, and the Yorubas and the Hausa/Fulanis and the northern ethnic groups in the country on the other hand.

The eighth moment was in 2007 regime transition period when the majority Hausa/Fulani ethnic group of the north and the majority Yoruba ethnic group of the west refused to let the lbo majority ethnic group of the east, or any of the minority ethnic groups in the country especially, in the Niger Delta region to produce the president of the country.

The marginalized Ibo majority ethnic group and the ethnic minorities of the former Eastern region had once seceded from the Nigerian Federation due to genocide against the groups and fear of political domination by the other ethnic majorities and minorities in the northern and in the western regions of Nigeria; and due to their perceived further marginalization in the country's political and economic processes should they continue to remain in the Nigerian federation. The secession led to a thirty month civil war that forced them back into the Nigerian federation. Since the end of the civil war, they have remained as "endangered species" in the Nigerian federation, suffering all forms of ethnically and religiously motivated attacks wherever they are found across the country; and have remained virtually excluded (marginalized) from the nation's economic and political processes. The marginalized Ibo majority ethnic group and the ethnic minorities of the former Eastern region are in the oil producing areas of Nigeria, and they are threatening to secede again from the rest of the country should they not be allowed to produce the next President. The ethnic groups of the former Eastern region are responsible for about $75 \%$ of the national foreign revenue earnings due to the mining of crude oil and natural gas in their regions.

These ethnic groups in the eastern Nigeria and the Niger Delta regions have not produced a Nigerian President with the exception of Dr. Nnamdi Azikiwe (an Igbo) who served as the Colonial Governor-General of the Federation, and as the first President of the Nigerian Federation when Nigeria became a republic in 1963. Effective political power was in the hands of the Prime-Minister Alhaji Abubakar Tafawa Balewa (a Hausa/Fulani). It would not be improper for one to say that since the inception of the country till date, that the majority and minority ethnic groups of eastern Nigeria have not produced an executive president of the country (Dr. Nnamdi Azikiwe lasted only three years in office (1963-1966) before being removed in a military coup; while Major General Aguiyi Ironsi, an Ibo Military officer that emerged after the coup lasted only six months in office before being killed in another military coup by General Yakubu Gowon, a Hausa/Fulani military officer. Ever since, all military coups have always been led by the Hausa/Fulani military officers); and two of the three elected executive presidents of the country- Alhaji Shehu Shagari and Alhaji Umaru Y'adua are from the Hausa/Fulani ethnic group; while the third - Retired General Olusegun Obasanjo is from the Yoruba majority ethnic group.

The demands of ethnic minorities of the Niger Delta and the Igbo ethnic majority in the eastern region are genuine and their threats are real. They already have ethnic militias - the Niger Delta Volunteer Force (NDVF): the Movement for the Actualization of the Sovereign state of Biafra (MASSOB); the Movement for the Survival of Ogoni People (MOSOP) and Movement for the Emancipation of the Niger Delta (MEND) that work towards the actualization of their goals politically independent ethnic regions, or the control of the economic resources in their ethnic regions, and the production of the occupants of the highest political posts in the country. But they are more inclined to secession than any other option 


\section{Why Have the Ethnic Majority Groups Refused to be Generous to the Minorities?}

All the factors identified by Hislope (1998) that militate against the generosity moments theory in a polity are all present in Nigeria except one - the fear that being generous would produce a "slippery slope" - or make the ethnic minorities become insatiable in their demands or hold the nation to ransom by making impossible demands:

a) the demographic pattern of the country,

b) the existence of contested borders,

c) historical memories of violence among the groups,

d) the multiplicity of ethnic groups in the country.

\subsection{The Demographic Pattern of the Country,}

The greatest of these impediments has been the demographic pattern of the country. The ascription of more than half of the nation's population to the former Northern region by the colonial administration in Nigeria has been at the centre of Nigeria's political crises. This has given the Northern Hausa/Fulani group the strength to dominate the political processes of the country since the colonial era to the present.

Population is about people and not about land mass. That the North has "two-thirds" of the landmass of Nigeria does not give it two-third of the nation's population. The colonial census gave the population density in the North to be 67 persons per square mile, and that of the East to be 269 per square mile, and that of the Western region to be 148 per square mile (Coleman, 1963; Sklar, 1963). How come the North has two-third of the country's population in the 1953 population that gave the densities, this was colonial calculations to impose the north on the rest of the country.

Though population census is not the issue under discussion here, it is pertinent to state that Nigeria is the only country in the world where more than half of the country's population live in the desert and sahel savannah regions of the North, while the flood plains and forest region of the South are uninhibited or unpopulated.

Population census has been one of the greatest sources of ethnic conflicts in Nigeria and will always remain so unless it is removed as criteria for representation in the national legislatures and a basis for revenue allocation to the regions. The 1962 population census was the first census conducted by an indigenous government in Nigeria and clearly showed that the Hausa/Fulani ethnic group of the North was not in fact the largest ethnic group in Nigeria. The Ibos of the East are, followed by the Yorubas of the West. The Hausa/Fulani is the third. This truth led to the cancellation of the census by the then Prime Minister Alhaji Abubakar Tafawa Balewa who happens to be of the Hausa/Fulani group (Ofiaja, 1979). The Prime Minister re-ordered another population census in 1963 that clearly gave two-thirds of the nation's population to the Hausa/Fulani group of the north.

Since the Hausa/Fulani can comfortably control the national government with or without any other ethnic group in the country due to this population advantage, it can and has always refused to be generous to the other ethnic groups in the country. The 2006 population census figure was another source of national/ethnic strife when it was released, and the National Assembly is yet to adopt and approve the report.

The ascription of more than half of the nation's population to the Hausa/Fulani ethnic group has enabled it to control the politics and administration of the country. It has also given it the opportunity to control the armed forces since the counter coup of July 1966, and about $60 \%$ of all the political appointments in the country. This population superiority has given the Northern elites the impetus to create more autonomous ethnic regions or states in their ethnic region than in any other ethnic regions in the country. The Hausa/Fulani ethnic group has been unfair to the other ethnic groups and there is an urgent need for them to be generous to the other ethnic groups in the nation's political process. This domination of the rest of the country by the north was crowned with Abacha's division of the country into six geo-political zones with three of geo-political zones in the north while the rest of the country was divided into three geo-political zones; and this division was tacitly approved with the imposition of an unworkable constitution on the country in 1999 by General Abdulsalami Abubarkar.

The demographic pattern of the country has made it impossible for the last factor identified by Hislope - the fear that being generous would make the ethnic minorities to be insatiable and hold the nation to ransom by making one impossible demand after another (creating a slippery slope) to hold as a factor. The emergence of Retired General Obasanjo as an elected civilian president in 1999 was not an act of generosity by the north to the rest of the country, but was because the entire southern Nigeria was united in seeing that the next Nigerian President does not come from the north; but from the Yoruba ethnic group as a remedy to the annulled "June 12" presidential election of 1993 which was won by Chief M. K. O. Abiola, a Yoruba man and annulled by General Ibrahim Babangida, a northerner of the 
Hausa/Fulani extract.

\subsection{Multiplicity of Ethnic Groups}

One important fact to note about the Nigerian nation is the multiplicity of ethnic groups in the country. Murdock (1959) in his study of Nigerian linguistic groups and cultures listed over four hundred ethnic groups whose populations ranged between five hundred and five million based on the 1921 census of Nigeria. According to Blitz (1965), the 1921 census figures was largely on estimates, and was the only one in the history of Nigeria that gave detailed information on the ethnic composition of the peoples especially, for the relatively small ethnic groups. Of the 416 known ethnic groups based on the 1921 census, 297 or $70 \%$ were located in the middle belt region; 75 or 18\% in the south; and 44 0r $9 \%$ in the north. The middle belt contained a larger proportion because it halted the northern intrusion into the south; and the downward state formation process by the Hausa/Fulani jihadists; (and also contained those fleeing from the north to the south due to the jihad; and also contained those fleeing from the south, northwards, due to the slave raids in the south).

The vegetation of the middle belt also provided difficult terrain for horse-riding invaders from the north thereby providing a place of refuge for those fleeing from the onslaught of the jihadists. It provided shelter for small heterogeneous groups that maintained their local identities, languages and cultures. The vegetation also discouraged the fusion of small ethnic groups into larger more homogeneous groups unlike what happened in the wide-open desert region of the north that encouraged expansion, interaction and fusion that formed the monolithic north of the Hausa/Fulani group. These ethnic nationalities now assert their local autonomiesand identities, and want to be recognized in the nation's socio-political processes. this makes the national political arena more difficult to understand and to predict.

\subsection{Historical Memories of Violence among the Groups and the Existence of Contested Boundaries.}

As Aderibigbe (1978) observed, the concept of Nigeria came in the much later period of colonialism. The peoples of modern day Nigeria lived in isolation until they were brought together by British rule (Burns, 1964; Crowder, 1962; Perham, 1961). Though they were linked together in various ways especially wars that resulted in conquests, overlordships, and, or, enslavements; there were still some forms of beneficial movements of people for trade purposes and movements of refugees who fled the harsh consequences of state formation processes and slave raids. These movements saw the formation of new settlements by diverse ethnic groups which gave rise to new social relations and ethnic cleavages. The peoples of Nigeria were therefore religiously and ethnically polarized before their unification into the modern Nigerian state in 1914 by Lord Lugard. Without this unification, what is today seen as Nigeria would have been more politically independent geo-political entities.

The intrusion of the Fulani group into the middle belt region (of the Tivs, Jokuns, Idomas, and the other minor ethnic groups in the region) started with alliances with factions of the indigenous ruling elites of the various ethnic nationalities they could not overrun during the jihads. Theruling elites in the unconquered ethnic nationalities were then gradually eliminated or gradual deposed and replaced with Hausa/Fulani elites or stooges from the ethnic nationalities to avoid civil unrest. So also was the same process employed in the deposition of traditional Yoruba elites in the Yoruba enclaves of Kabba, llorin and Kwara in the northern fringes of the Yoruba ethnic region, and in the incorporation of the Igalas in the northern fringes of the Igbo ethnic region into the Hausa/Fulani feudal oligarchy before Nigerian independence. These depositions have become sources of perennial border and power conflicts in the regions between the Hausa/Fulani settlers and the indigenous populations especially in the middle belt region especially the plateau areas of Jos; llorin, and other parts of the north and the middle-belt where the Hausa/Fulani group claims ownership as a result of the Usman Danfodio's jihad.

Political power has been more at the root cause of the crises and the essence is to control the economic resources available in the regions for selfish ends. With the globalization of democracy, colonialism, either external or internal in form, is incompatible with modern civilization and must be opposed by all means at all costs. One should expect more ethnic conflicts in a country with so many ethnic groups under the authority of a government; especially in the middle belt region than in any other region in the country as the region was a melting pot for the various ethnic nationalities that settled in the area. Conflict over farm lands, water supply sources, and political leadership came to the fore and has presented themselves more as religious conflict in contemporary Nigeria.

The dangers of mixing religion with politics in Nigeria have been seen in all the bloody ethnic conflicts of the 1980s that were religiously motivated. The Kasuwa-Mangani communal crisis of 1980; the Zangon Kataf and Gure-Kahugu 
crisis of 1984; the Kaganchan and Lere crisis of 1987; the llorin and Jere crisis of 1989; the 1991 crisis in Tafawa Balewa; the Zango Kataf crisis of 1992 and the Jos crises of 2006 and 2010 in which the migrant Fulani settlers have consistently persecuted the indigenous populations especially Christian in their midst are good pointers that ethnic conflicts under the guise of religious conflicts are incompatible to peace, unity and development of democratic governance in Nigeria, and is an agent of under-development in any country where it is found.

\subsection{The Fear that Being Generous would Make the Ethnic Minorities to Become Insatiable.}

There has never been a case in the Nigerian political process where the majority ethnic groups have been generous to the minority ethnic groups. From the colonial era to independence, the minority ethnic groups within the then three geopolitical zones in the country (the eastern, western and northern regions) were marginalized economically and politically. This led to a series of minority protests and agitations for the creation of autonomous geo-political zones for them within the three regions. The protests and agitations later led to the establishment of the Sir Henry Wilink's Minority Commission by the colonial government to look into the problems of the minority ethnic groups in the country and make recommendations to the government. Despite state creation exercise by subsequent governments in the country, ethnic conflicts and agitations for the creation of more autonomous regions have been on the increase in the country.

The emergence of Chief M.K.O. Abiola (a member of the majority Yoruba ethnic group) as the winner of the annulled June 12, 1993 presidential election was not due to any generosity. The emergence of Retired General Olusegun Obasanjo (a member of the majority Yoruba ethnic group) as the a civilian head of state during the political transition period of General Abdulsalami Abubakar of 1999 was not also a generosity by the Hausa/Fulani majority ethnic group. And the selection of Dr. Jonathan Goodluck (from ljaw - one of the minority ethnic groups in the Niger Delta) as the vice-presidential candidate of the Peoples Democratic Party (PDP) was not a generous act to the minorities of the Niger Delta because any other party could have wonnthe election, but a political strategy by the PDP to win the 2007 election.

For there to be an act of generosity, the majority ethnic tribes must consciously agree to allow the minority ethnic groups to produce the occupants of the highest political posts in the country and in the states of the federation. There has to be a tacit agreement by the elites of the groups on how and when these should take place. And the arrangement should follow a regular pattern guaranteed by the constitution or any other legal document.

\section{Generosity as Solution to Ethnic Conflicts in Nigerian}

There are very good prospects of the generosity moments theory being a good antidote to the ethnic conflicts in Nigeria. The zoning system adopted by the NPN in 1979 and PDP in 1999 seem to be very close to the generosity concept and indicate that the country could have peaceful political and regime transitions if the structural factors that can ensure respect and adherence to the zoning arrangements are put in place. Experiences from the zoning system has shown that transitions could be smooth, peaceful and the legitimacy of the regime secured when political posts are properly zoned to ethnic nationalities but the elites of the majority ethnic groups are not prepared to be generous enough to allow the posts to rotate among the various ethnic groups in the nation due to the economic and social benefits that accrue to them. Otherwise, the generosity moment theory offers a very good solution to the ethnic conflicts endemic in Nigeria's political process.

For the ethnic majorities to be generous to the ethnic minorities in the country, a lot of structural factors have to be put in place to ensure its success - a constitutional review that should include these:

a) The country should constitutionally revert to the three-regional arrangement that existed during the colonial period - the Eastern, Western and Northern regions and the highest political offices at the national level should be constitutionally made to rotate among the regions in a fixed order. (These three geo-political regions were the federating units that formed the Nigerian federation. The creation of six geo-political zones by the northern military elites is against the spirit under which the Nigerian federation was formed and reinforces the internal colonization of the rest of the country by the Hausa/Fulani ethnic group). If the Presidency is zoned to the northern region, the Vice-President to the western region; and the Speaker of the National Assembly to the eastern region in any regime transition period by the constitution, all political parties in the country are bound to sponsor only northern presidential candidates with western vice-presidential candidates; while the party with majority seats in the National Assembly would elect a speaker from the eastern region. This arrangement would change at the expiration of the tenure of the regime. In the next 
regime, the presidency would go to the next region. This rotation could take the alphabetical order to avoid confusion - the eastern region first; followed by the northern region, and then the western region. And the regions would work out the order in which these national posts would rotate among the component states in fixed turns to avoid crises.

b) The political parties should be constitutionally bound to respect the zoning system and made to work out and submit to the Electoral Commission and the Supreme Court of Nigeria, a detailed account of how national, regional, state, and local government political posts are zoned to all the regions in the federation; to all the states in the region; to all senatorial districts of the states; to all the local government areas in the senatorial district and to all wards in the local government. It should also specify how state political posts are zoned to the component senatorial districts in the state, and to the local governments in the senatorial districts in turns; and how local government political posts are zoned to the component communities or wards in the local governments in turns. This would remove the internal colonization that go on in most of the states in the country, as most states in Nigeria contain majority and minority ethnic populations. Certain minority sections of some states find it extremely impossible to produce the governors or other principal political officers of their states and or local governments. The zoning system would also help to solve the problems of personality clashes and politically motivated assassinations rife in the Nigerian polity.

In the event of the sudden exit of any of the political officers, the political parties in the ethnic origin of the exited political officer would come together to select and elect a replacement. The selection and election processes should be based on the zoning system adopted by the party in the region as each political party would be made to adopt a zoning system for each of the regions which must be deposited with the Supreme Court and the Electoral Commission before the general elections.

It is the zoning system among other things that gives a party an edge over the others in the elections as the political party with the best zoning system would sweep the polls. People would embrace political parties with the most appealing manifestoes and most favorable zoning systems. And once a zoning system has been adopted, it should form an entrenched part of the party's constitution and shall not be easily changed.

It must be noted that judicial and the civil service posts and positions shall not be zoned. This is to protect their independence, neutrality and integrity of the judiciary and the civil service and to reposition the judiciary and the civil service to check the abuse of powers by the political class.

c) There should be a constitutional provision for a unicameral national legislature with representation based on the equality of regions; a unicameral regional legislatures with representation on equality of states basis; unicameral state assemblies with representation on equality of local governments; and unicameral local government legislatures with representation on equality of wards. This will help to create healthy legislatures across the country where no one would feel superior or inferior to the other; and where national and local matters would be discussed with respect for one another and on level playing grounds without fear or favor. This would also help curb the formation of dubious political groups and unholy alliances among political parties that is characteristic of the Nigerian political process. It will usher in transparency and accountability in governance, check corruption and abuse of office by public office holders.

d) Each geo-political zone should have regional executive and legislative arms of government with the powers to create states and local governments in their geo-political zones. This would ensure that all ethnic groups in the regions are given a sense of belonging to the Nigerian state through state and local government creation and good governance. State and local government creation should not be at the mercy of the federal government because our past political leaders have abused the state and local government creation exercises in the country by creating more states and local governments in their ethnic regions.

The creation of regional governments would make more money and resources available to the states and the local government areas, directly from the regional governments and the failure of any state or local government to develop would be blamed on the natural indigenes of the local government who rule and administer the local government. This implies that only the natural indigenes of a local government should be constitutionally allowed to contest elections into the local government area and elected to take charge of the affairs of the local government area, and be employed in the local government service for the administration of the local government. This would help abolish the pockets of powers created by some ethnic majorities and minorities within the states, check corruption and lack of accountability and transparency in governance which have led to infrastructural decay and the neglect of certain sections of the states and local governments that did not support the party in power, or produce the ruling elites at the particular point in time. It will also help to 
check unemployment in all the local governments across the country. There exist ethnic dichotomies in almost all states of the federation and the internal colonization of communal/linguistic groups by others like what happens in the present day Enugu, Abia, Akwa Ibom, Delta, Edo, Kogi and Cross River States just to mention but a few.

e) The tenure of a regime should be constitutionally pegged at five years only and each geo-political zone should produce state officials in turns, for a fixed tenure of five years without an option of a second term in office or re-election. This would enable governance rotate fast among the ethnic regions and groups in the country.

f) Any Nigerian citizen who has served a particular regime at any level or tier of government should be constitutionally barred from serving in another regime until after ten years of his /her exit from service. This will help to bring out better and highly talented Nigerians for public service, prevent corruption and the abuse of power; and, the domination of the Nigerian political process or scene by one particular group of national elites and by a particular generation of rulers. It is disheartening to find those that ruled Nigeria in the late 1960s still holding onto power till present. This will help right the wrongs committed by a regime early enough to promote the peace, unity and progress of the nation.

g) The census figures should be constitutionally barred from being the basis for representation in any legislature in the country. Representation in the national legislatures should be on equality of regions, and representation in the regional legislatures should be on the equality of states; and representation in the state legislature should be on the equality of local government areas in the state; while representation in the local government legislature should be on the equality of wards.

h) The population figures should also be constitutionally barred from being the basis for revenue allocation in the country. This will help remove the conflicts over population census figures and revenue allocation in the country; and direct the efforts of the political leaders to more meaningful ventures. Revenue allocation should be based more on derivation, rather than on any other principle. States with large populations would thus be in good positions (advantage) of having large chunks of their internally generated funds from taxation of the large populations.

i) Revenue allocation formula for the country should be constitutionally changed to be thus:

- $20 \%$ derivation to regions

- $45 \%$ to the regions, (i.e. $15 \%$ to each of the three geo-political regions of East, North and West)

- $35 \%$ to the federal government.

Any geo-political entity that feels it has more population than the others should harness that population to its advantage. Collect taxes from the population based on federal tax laws to boost its internally generated funds. This would make tax evasion a very serious crime as most of our businessentities dodge tax payment. While the tax laws are made by the central government to create uniformity and order in the tax system and for national unity; the administration of the laws remains the duty of the local governments that would utilize the funds as part of their statutory allocation for each year. And the regions should see to the financial and development needs of the states and local governments in their regions

j) Each federal ministry, parastatal or commission should have three ministerial appointees, one from each region. This would enable the federal ministry or agency to coordinate and harmonize its functions evenly across the country, create sense of belonging in all the regions, and promote national unity. It is on record that since the inception on Nigeria, the ministers of agriculture and water resources have always come from one particular geo-political region of the country. With three ministers in the ministries, water resources and agricultural production would be evenly developed across the country thereby making the country meet its food production needs and water needs.

k) The salaries and allowances of all political appointees at the federal level shall be paid by their regional governments from their respective regional allocations. The essence is to allow more monies at the federal level to run the national government, and to make politics a calling to serve humanity rather than an avenue to quick riches. This will certainly curb the ostentatious life styles of our political leaders as the regions would not afford to support frivolous life styles by the political class from their meager financial allocations.

\section{Summary and Conclusion}

This paper has examined ethnic conflicts in Nigeria noting that the conflicts had been in existence between the various ethnic nationalities that comprise the country long before the colonization of the country by the British; and that the 
colonization of Nigeria only brought the ethnic conflicts to the national political scene. It also observed that these ethnic conflicts are caused by regional struggles over economic resources, foreign influences, and education (social mobilization); and would continue to persist due to the economic and social benefits that accrue from it, especially to the various ethnic elites who employ it in national struggles for resources and positions.

The paper also observed that ethnic conflicts took a national outlook with the colonization and unification of the various ethnic nationalities into a country called Nigeria. Ever since, ethnicity has become a potent force in Nigeria's political process; and that the various governments in Nigeria have used administrative panels of inquiry, state creation exercises, the federal character principle and military expeditions to address ethnic conflicts in the country, and that these measures have not been very effective.

The application of Hislopes generosity moments theory to problems of ethnic conflicts and democratic governance in Nigeria appears as a workable solution. If this is applied, ethnic conflicts in the country would certainly be less severe and less violent. The zoning system adopted by some political parties (the National Party of Nigeria -the NPN, and the Peoples Democratic Party - the PDP) in Nigeria were good step towards the use of the generosity moments theory in solving ethnic conflicts in the Nigerian political process.

The paper further observed that though some structural factors exist that militate against the use of the generosity moments, it suggested constitutional changes that can remove such structural factors to ensure that the ethnic majorities become generous to the ethnic minorities in the political process.

\section{Notes}

1. The colonial government instituted the Sir Henry Willink's Minority Commission on September 27, 1957 to investigate the complaints of the various ethnic minorities in the then three geo-political zones that formed the country - the Eastern, Northern and Western Regions. They were the federating units in the formation of Nigeria.

2. The pattern of state creation in Nigeria have been based on political considerations rather than the need for the development of the regions.

3. See the fundamental objectives and directive principles of state policy of Nigeria in the various indigenous Nigerian constitutions (1979, 1989, 1999 Constitutions)

4. General Olusegun Obasanjo as a civilian Head of State sent military expeditions to Odi, Bayelsa State; and Zongon Kataff, Kaduna State to quell ethnic crises

5. The zoning system as introduced in Nigeria's political process by the National Party of Nigeria in 1979 as winning strategy and was abused by the northern members of the party in 1983 when the western and eastern regional members of the party wanted to invoke the principle for either of them to produce the next presidential candidate for the party for the 1983 presidential election. The crises of confidence generated by the issue among the ruling elite was in part why the military under the leadership of General Buhari took over political power in 1983. The coup was part of the Northern scheme to hold perpetually onto power in the country. So also were the other coups designed to work to the Hausa/Fulani advantage and cling onto political power.

\section{References}

Achebe. Chinua (1983) The Trouble With Nigeria. Enugu: Fourth Dimension.

Aderibigbe, A. A. B. (1978) "Peoples of Southern Nigeria" in, Ade Ajayi J.J. and Espie lan (1978) A Thousand Years of African History. Lagos: Thomas Nelson and sons.

Akpofure, Rex and Michael Crowder (1966) Nigeria: A Modern History for Schools. London: Faber.

Awolowo, Obafemi (1947) Path to Nigerian Freedom. London: Macmillan Press Limited.

Awolowo, Obafemi (1966) Thoughts on the Nigerian Constitution. Ibadan: Oxford University Press.

Blitz, Franklin L. (ed.) (1965) The Politics and Administration of Nigerian Government. London: Sweet and Maxwell.

Burns, A.C. (1964) History of Nigeria. London: Allen and Unwin.

Coleman, R. (1963) Nigeria: Background to Nationalism. Berkley: University of California Press

Crowder, Michael (1962) The Story of Nigeria. London: Faber and Faber

Deutsch, K. W. (1961) "Implications of social Mobilization for the Politics of of Development" in, Jean Blondel (ed.) Comparative Politics: A Reader. London: Macmillan Press Limited.

Ellah, Francis (1983) Nigeria and State Creation Based on The Unfinished Motion. Port-Harcourt: Ellah snd Sons Publishers.

Hislope, Robert (1998) "The Generousity Moment: Ethnic Politics, Democratic Consolidation and State in Yugoslavia (Croatia), South Africa and Czechoslovakia" Democratization. Vol.5, No1, pp.64-88 
Ifemesia, C. C. (1965) "The State of The Central Sudan: Kanem Borno and the Hausa States" in, Ade Ajayi J.J. and Espie lan (1978) A Thousand Years of African History. Lagos: Thomas Nelson and sons.

Igwe, Obasi (2002) Politics and Globe Dictionary. Enugu: Jamoe Enterprises.

Ikejiani, O. and Ikejiani M. (1986) Nigerian Political Imperatives: Desiderata for Nationhood and Stability. Enugu: Fourth Foundation.

Nnoli, Okwudiba (1988) Ethnic Conflicts in Africa. Senegal: CODESRIA.

Ofiaja, Nicholas (1979) Stability and Instability in Politics: The Case of Nigeria and Cameroun. New York: Vintage Press.

Ojiako, James (1981) Nigeria: Yesterday, Today and..? Onitsha: Africana Educational Publishers.

Sklar, Richard L. (1963) Nigerian Political Parties. Enugu: Nok Publishers.

Tamuno, T. N. (1965) "Peoples of the Niger-Benue Confluence" in, Ade Ajayi J.J. and Espie lan (1978) A Thousand Years of African History. Lagos: Thomas Nelson and sons.

Murdock, G.P.(1959) Africa, Its peoples and Their Culture History. New York: McGraw-Hill

Perham, Margery (1961) Native Administration of Nigeria. London: Oxford University Press 